\title{
Effect of triamcinolone in keloids morphological changes and cell apoptosis
}

\section{Efeito da triancinolona na apoptose celular e nas alterações morfológicas em queloides}

João Márcio Prazeres dos Santos'; Cláudio de Souza,ACbC-MG²; Anílton César de Vasconcelos²; Tarcizo Afonso Nunes²

\author{
A B S S T R A C T
}

\begin{abstract}
Objective: to assess the effects of injectable triamcinolone on keloid scars length, height and thickness, and on the number of cells undergoing apoptosis. Methods: This study consists in a prospective, controlled, randomized, single-blinded clinical trial, conducted with fifteen patients with ear keloids divided into two groups: group 1 - seven patients undergoing keloid excisions, and group 2 eight patients undergoing keloid excisions after three sessions of infiltration with one $\mathrm{ml}$ of Triamcinolone hexacetonide (20mg/ml) with three week intervals between them and between the last session and surgery. The two groups were homogeneous regarding age, gender and evolution of the keloid scar. The keloid scars of patients in group 2 were measured for the length, height and thickness before triamcinolone injection and before surgery. A blinded observer performed morphological detailing and quantification of cells in hematoxylin-eosin-stained surgical specimens. An apoptotic index was created. Results: The apoptotic index in group 1 was 56.82, and in group $2,68.55$, showing no significant difference as for apoptosis $(p=0.0971)$. The reduction in keloid dimensions in Group 2 was $10.12 \%$ in length $(p=0.6598), 11.94 \%$ in height $(p=0.4981)$ and $15.62 \%$ in thickness $(p=0.4027)$. Conclusion: This study concluded that the infiltration of triamcinolone in keloid scars did not increase the number of apoptosit and did not reduce keloids' size, length, height or thickness.
\end{abstract}

Key words: Apoptosis. Keloid. Triamcinolone Acetonide. Wound Healing

\section{INTRODUCTION}

K eloids are fibroproliferative disorders ${ }^{1}$ occurring in five to $15 \%$ of scars, regardless of gender ${ }^{2}$. They may be caused by inability of the body to interrupt the healing process, causing excess cell proliferation and increased collagen production ${ }^{3}$. Apoptosis is the most appropriate way to adjust the amount of fibroblasts and other cells during healing, as well as in other physiological events, by presenting less inflammation and being a regulated process ${ }^{4}$.

Researches have not achieved complete success in elucidating keloids' causes and, as a consequences, treatments are varied and not always show good results ${ }^{2,3}$. The therapeutic approach currently adopted for keloids consists of several options and, among them, are surgical resection and intralesional corticosteroid infiltration ${ }^{5-8}$. Glucocorticoids are used for at least five decades ${ }^{7}$ and act by decreasing the inflammatory process, which could be one of keloids' causes. However, this may be just one of the actions ${ }^{9}$. Investigations with in vitro fibroblast cultures have aimed at elucidating the effects of corticosteroids on apoptosis ${ }^{10,11}$. This fact motivated us to investigate the effects of triamcinolone in the in vivo keloid scar.
The objective of this study was to assess the effects of injectable triamcinolone in keloid scars on the number of cells undergoing apoptosis and changes in scars' length, height and thickness.

\section{METHODS}

The research was conducted at the surgery clinic of the Hospital Escola da Faculdade de Medicina de Barbacena (Centro de Especialidades Médicas - CEMED) and at the Laboratório de Apoptose, Instituto de Ciências Biológicas (ICB) of UFMG, after approval by the Comitê de Ética em Pesquisa (CEP) of UFMG (\# 0601.0.203.00011), as well as by the Comitê de Ética em Pesquisa of the Universidade Presidente Antônio Carlos (UNIPAC) (\# 911/ 2011).

This was a longitudinal, prospective, controlled, randomized, single-blinded clinical study ${ }^{12}$, which included individuals with keloid scars located in the earlobe due to piercing and who agreed to participate by signing an informed consent form. We excluded individuals who had previous scar treatment, use of antimitotic and/or

1. Disciplina de Clínica Cirúrgica do Adulto I, Faculdade de Medicina de Barbacena - MG - Brazil; 2. Faculdade de Medicina, Universidade Federal de Minas Gerais (UFMG) - MG - Brazil. 
immunomodulatory drugs or individuals not willing to participate in the survey.

The subjects were interviewed for anamnesis and the sample consisted of 15 individuals, seven $(46.67 \%)$ male and eight (53.33\%) females, three white, seven brown and five black $(p=0.782)$.

We randomly created two groups of subjects: Group 1 - seven (46.67\%) patients who underwent resection of keloids; and Group 2 - eight (53.33\%) subjects who received intralesional corticosteroid infiltration prior to surgical resection.

All patients underwent extramarginal surgical resection of the keloids followed by suture with separate 60 Nylon monofilament stitches. The removal of the lesion was the only procedure in Group 1 individuals.

In Group 2, keloid scars were measured in centimeters in length, height and thickness, with the help of graph caliper (Rhosse $囚$, São Paulo). Then we conducted three infiltration sessions of triamcinolone hexacetonide $1 \mathrm{ml}$, at a concentration of $20 \mathrm{mg} / \mathrm{mL}$, in the central region of keloid scar; the sessions were three weeks apart ${ }^{10,11}$. Three weeks after the last infiltration session we repeated the keloid scars measurements, followed by their resection. Were removed the stitches ten days after surgery and individuals returned to monthly assessment for six months.

Surgical specimens were divided into three fragments of up to $0.5 \mathrm{~cm}$ thick by longitudinal section, including the center and border of the lesion. All fragments were sent to the Laboratório de Apoptose at the UFMG, wherein one fragment was placed in a $\mathrm{pH} 7.4$ buffered $10 \%$ formalin for analysis and the other two fragments were placed in vials with glutaraldehyde and liquid nitrogen to other research.

The specimens fixed in formalin were processed according to routine techniques, cut in $5 i m$ slices and stained with hematoxylin-eosin (HE) to morphological detailing.

We used the light microscope Olympus $\mathrm{CH} 300$, with plan achromatic objective lenses with 40-times magnification; we also obtained photographs scanned through a JVC ${ }^{\circledR}$ TK $720 \mathrm{~V}$ camera attached to the microscope to capture by Honestech $\operatorname{TVR}^{\circledR}$ images analyzer, version 2.5 for Windows ${ }^{\circledR}$.

The quantification of the cells was performed manually in scanned images obtained from histological fields and analyzed with the software Image-Pro Plus ${ }^{\circledR}$, version 4.5.0.29, with five fields obtained for each slide, and averaged between these measurements. This assessment was made by a single masked observer, which regarded as apoptotic the cells that had three or more of the following morphological characteristics: anoiquia, condensation of cytoplasm, nuclear condensation, nuclear fragmentation and cell fragmentation. The apoptotic index (Al) was determined by the following formula: $\mathrm{Al}=$ number of apoptotic cells X100 / number of total cells.

We carried out TUNEL (terminal deoxynucleotide transferase-mediated dUTP Nick-End Labelin) reactions to confirm the presence of apoptotic cells evidenced in the cytomorphological analysis (TdT-FragEL DNA Fragmentation Detection Kit ${ }^{\circledR}$ TM, Calbiochem).

We employed nonparametric tests (MannWhitney), since groups showed asymmetric distribution and reduced number of individuals ${ }^{13,14}$. We adopted the significance level of $5 \%(p<0.05)$.

\section{RESULTS}

The age ranged from 12 to 35 years; group 1 had a mean age of 19.29 years $( \pm 4.645)$ and group 2, 35.38 years $( \pm 30.336)(p=0.779)$. There was a predominance of browns and blacks in both groups, six individuals in each group, which corresponded to $85.8 \%$ in group 1 and $75.0 \%$ in group 2 .

When comparing the initial with the final measurements of Group 2 individuals, after corticoid infiltration the keloid scars showed an average reduction in dimensions, $10.12 \%$ in length, $11.94 \%$ in height and $15.62 \%$ in thickness, with no significant difference ( $p>0.05)$ (Table 1).

In Group 1 individuals, without the infiltration of triamcinolone in keloid scars, the apoptotic index was 56.82 $( \pm 15.82)$, while in Group 2, with triamcinolone infiltration, this index was $68.55( \pm 9,32)$, with no significant difference $(p=0.0971)$. We observed no side effect of steroid use in Group 2 subjects.

\section{DISCUSSION}

The differentiation between keloids and hypertrophic scars is authoritative, because, although they have the same probable etiology, they exhibit differences in clinical presentation and treatment. For example, hypertrophic scars tend to regression ${ }^{15,16}$ and keloids present in several locations ${ }^{2,9}$. We then restricted the inclusion in the study to individuals with keloids on the ear lobe, so the sample would be homogeneous. Trauma is essential to trigger the keloids formation process, and can be a response to insect bites ${ }^{9}$, acne $^{3}$, surgical incisions ${ }^{17}$ and piercings, as in all this study's subjects.

In this series, $80 \%$ of subjects had pigmented skin, considering the members of both groups with black or brown skin, according to previous assessments $9,16,18$. As in the literature, we found a predominance of keloids between the second and third decades of life $e^{9,16,18}$ and there was no difference in gender distribution between groups $(p=0.782)^{17}$. There was also no difference $(p=0.779)$ as to the keloids evolution time, what prevented the results to be influenced by more resistance of mature lesions ${ }^{19,20}$.

Triamcinolone infiltrations were performed in the central region of keloids with the aim of causing more 
Table 1 - Initial and final dimensions of keloid scars of Group 2 individuals.

\begin{tabular}{lcrc}
\hline Dimensions & Initial $\bar{\chi} \pm$ sd & Final $\bar{\chi} \pm$ sd & $\mathrm{p}^{*}$ \\
\hline Lenght $^{\mathrm{a}}$ & $1.363 \pm 0.6413$ & $1.225 \pm 0.5800$ & 0.6598 \\
Height $^{\mathrm{a}}$ & $0.8375 \pm 0.3114$ & $0.7375 \pm 0.2615$ & 0.4981 \\
Thickness $^{\mathrm{a}}$ & $0.8000 \pm 0.3071$ & $0.6750 \pm 0.2712$ & 0.4027 \\
\hline
\end{tabular}

a: measure in centimeters; : Average; SD: standard deviation; *: Mann-Whitney test.

effects, since this site's fibroblasts are more metabolically active $^{21}$. There is no consensus on the dose of corticosteroids to be used $\mathrm{d}^{2,8,9,11}$ and the concentration of $20 \mathrm{mg} / \mathrm{mL}$ is one commercially available presentation. The option of performing injections at three-week intervals was due to pharmacokinetics, as the drug form local depot and produces effect for 21 days, on average. The use of steroids may be accompanied by side effects, such as atrophy, depigmentation, telangiectasia, necrosis, ulceration and Cushing's syndrome ${ }^{2,17,18,22}$. The absence of side effects in this study could be due to treatment not being extended over three sessions and to the used concentration of $20 \mathrm{mg} /$ $\mathrm{mL}$ triamcinolone. This suggests the possibility of further investigation of such effects when using corticosteroids for more sessions or in higher concentrations. The clinical application of corticosteroids is one of the therapeutic resources to decrease keloid masses $7,8,18$ and can be supported by the reduction in keloids size in this survey, which was $12.56 \%$ on average when jointly considering length, height and thickness.

The comparison of the apoptotic index between groups 1 and 2 showed no significant difference ( $p=0.0971$ ), which can be explained by several reasons: small sample; speed with which apoptosis occurs, with the possibility of lasting only 24 hours, as described by Kerr, Wyllie and Currie, in 1972 ${ }^{23}$; and the fact that keloids present heterogeneous tissues, despite all attempts by authors to homogenize the sample. Although research has not shown significant increase in apoptosis in infiltrated keloids, this increase is worthy of attention, since keloids' fibroblasts are more resistant to apoptosis and display apoptosis rates $22 \%$ lower when compared with fibroblasts from normal skin or from scars considered norma ${ }^{24}$.

The TUNEL assay is an assay for DNA fragmentation and detection. Although not specific to apoptosis, since necrosis can also display this fragmentation, this reaction has been widely used to quantify apoptosis, both in cell cultures and preserved in frozen tissue, formalin or paraffin ${ }^{25}$. The TUNEL assay is a reliable method for apoptosis detection, especially when confirmed by another method such as cytomorphological analysis ${ }^{25}$.

The need for the use of these tests has disadvantages, because for values to be significant, $p<0.05$, samples should be higher or the difference between them must be the greatest possible ${ }^{14}$. These two conditions were not met in this research.

Due to sample size and results obtained, other studies should be proposed in order to evaluate the role of triamcinolone in apoptosis, as well as investigations of other mechanisms of action of this drug on scars.

The infiltration of triamcinolone in keloid scars did not increase the number of apoptoses and caused no reduction in dimensions, length, height and thickness of infiltrated keloids.

\title{
R E S U M O
}

\begin{abstract}
Objetivo: comparar o efeito da triancinolona injetável em cicatrizes queloidianas quanto ao número de células em apoptose e avaliar o efeito da triancinolona quanto às alterações no comprimento, altura e espessura dessas cicatrizes. Métodos: estudo clínico longitudinal, prospectivo, controlado, aleatorizado, unicego, com 15 pacientes portadores de queloides de orelha distribuídos em dois grupos: grupo 1, com sete pacientes submetidos apenas às exéreses dos queloides; e grupo 2, com oito pacientes submetidos às exéreses das lesões após três sessões de infiltração de $1 \mathrm{ml}$ de hexacetonida de triancinolona (20mg/mL), com intervalos de três semanas entre elas, assim como entre a última sessão e a operação. Os dois grupos foram homogêneos quanto à: idade ( $p=0,867)$, sexo $(p=0,782)$ e tempo de evolução da cicatriz queloidiana $(p=0,779)$. As cicatrizes queloidianas dos pacientes do grupo 2 foram medidas quanto ao comprimento, altura e espessura antes da injeção da triancinolona e antes do procedimento cirúrgico. Um observador mascarado realizou detalhamento morfológico e quantificação das células nas peças cirúrgicas, coradas com HE. Foi criado um índice apoptótico. Resultados: os dois grupos foram homogêneos quanto à: idade $(p=0,867)$, sexo $(p=0,782)$ e tempo de evolução da cicatriz queloidiana $(p=0,779)$. o índice apoptótico no grupo 1 foi 56,82 e no grupo 2, 68,55, sem diferença ( $p=0,0971$ ). As reduções nas dimensões dos queloides dos grupos 2 foram 10,12\% para o comprimento ( $p=0,6598$ ), 11,94\% para a altura $(p=0,4981)$ e $15,62 \%$ para a espessura $(p=0,4027)$. Conclusão: a infiltração de triancinolona nas cicatrizes queloidianas não aumentou o número de apoptoses e não houve redução das dimensões, comprimento, altura e espessura dos queloides.
\end{abstract}

Descritores: Apoptose. Queloide. Triancinolona Acetonida. Cicatrização. 


\section{REFERENCES}

1. Tredget EE, Nedelec B, Scott PG, Ghahary A. Hypertrophic scars, keloids, and contractures. The cellular and molecular basis for therapy. Surg Clin North Am. 1997;77(3):701-30.

2. Ceoviæ R, Lipozenciæ J, Bukviæ Mokos Z, Stulhofer Buzina D, Kostoviæ K. Why don't we have more effective treatment for keloids? Acta Dermatovenerol Croat. 2010;18(3):195-200.

3. Shih B, Garside E, McGrouther DA, Bayat A. Molecular dissection of abnormal wound healing processes resulting in keloid disease. Wound Repair Regen. 2010;18(2):139-53.

4. Ferrari CKB. Apoptose: a importância da maquinaria de morte celular no controle e na patogêneses das doenças. Rev ciênc méd. 2000;9(1):21-31

5. de Oliveira GV, Nunes TA, Magna LA, Cintra ML, Kitten GT, Zarpellon $S$, et al. Silicone versus nosilicone gell dressings: a controled trial. Dermatol Surg. 2001;27(8):721-6.

6. Carroll LA, Hanasono MM, Mikulec AA, Kita M, Koch RJ. Triamcinolone stimulates bFGF production and inhibits TGF-beta1 production by human dermal fibroblasts. Dermatol Surg. 2002;28(8):704-9

7. Muneuchi G, Suzuki S, Onodera M, Ito O, Hata $Y$, Igawa HH. Long-term outcome intralesional injection of traimcinolone acetonide for the treatment of keloids scars in Asian patients. Scand J Plast Recontr Surg Hand Surg. 2006;40(2):111-6.

8. Widgerow AD, Chait LA, Stals PJ, Stals R, Candy G. Multimodality scar management program. Aesthetic Plast Surg. 2009;33(4):53343.

9. Juckett G, Hartman-Adams H. Management of keloids and hypertrophic scars. Am Fam Physician. 2009;80(3):253-60.

10. Darougheh A, Asilian A, Shariati F. Intralesional triamcinolone alone or in combination with 5-fluorouracil for the treatment of keloid and hupiertrophic scars. Clin Exp Dermatol. 2009;34(2):219-23.

11. Durani $P$, Bayat $A$. Levels of evidence for the treatment of keloid disease. J Plast Reconstr Aesthet Surg. 2008:61(1):4-17.

12. Hochman B, Nahas FX, Oliveira Filho RS, Ferreira LM. Desenhos de pesquisa. Acta Cir Bras. 2005;20(supl 2):2-9.

13. Siqueira AL, Tibúrcio JD. Estatística na área de saúde: conceitos, metodologia, aplicações e prática computacional. Belo Horizonte: Coopmed; 2011.

14. Triola MF. Introdução à estatística. Atualização da tecnologia. 11ª ed. Rio de Janeiro: Livros Técnicos e Científicos; 2013.
15. Gupta S, Sharma VK. Standard guidelines of care: Keloids and hypertrophic scars. Indian J Dermatol Venereol Leprol. 2011;77(1):94-100.

16. Wolfram D, Tzankov A, Pülzl P, Piza-Katzer H. Hypertrophic scars and keloids - a review of their pathophysiology, risk factors, and therapeutic management. Dermatol Surg. 2009;35(2):171-81.

17. Al-Attar A, Mess S, Thomassen JM, Kauffman CL, Davison SP. Keloid pathogenesis and treatment. Plast Reconstr Surg. 2006;117(1):286-300

18. Mustoe TA, Cooter RD, Gold MH, Hobbs FD, Ramelet AA, Shakespeare PG, et al. International clinical recommendations on scar management. Plast Reconstr Surg. 2002;110(2):560-71

19. Ueda K, Furuya E, Yasuda Y, Oba S, Tajima S. Keloids have continuous high metabolic activity. Plast Reconstr Surg. 1999;104(3):694-8.

20. Wang XQ, Liu YK, Qing C, Lu SL. A review of the effectiveness of antimitotic drug injections for hypertrophic scars and keloids. Ann Plast Surg. 2009;63(6):688-92.

21. Lu F, Gao J, Ogawa R, Hyakusoku H, Ou C. Biological differences between fibroblasts derived from peripheral and central areas of keloid tissues. Plast Reconstr Surg. 2007;120(3):625-30.

22. Rhen T, Cidlowski JA. Antiinflammatory action of glucocorticoidsnew mechanisms for old drugs. N Engl J Med. 2005;353(16):171123.

23. Kerr JF, Wyllie AH, Currier AR. Apoptosis: a basical biological phenomenon with wide-ranging implications in tissue kinetics. $\mathrm{Br} J$ Cancer. 1972;26(4):239-57.

24. Ladin DA, Hou Z, Patel D, McPhail M, Olson JC, Saed GM, et al. p53 and apoptosis alterations in keloids and keloid fibroblasts. Wound Repair Regen. 1998;6(1):28-37.

25. Huerta S, Goulet EJ, Huerta-Yepez S, Livingston EH. Screening and detection of apoptosis. J Surg Res. 2007;139(1):143-56.

Received on 15/07/2014

Accepted for publication 05/09/2014

Conflict of interest: none.

Source of funding: none.

Address for correspondence:

João Márcio Prazeres dos Santos

E-mail: jmprazsantos@hotmail.com 